\title{
Spawn of Satan?
}

\section{Widespread egg donation has led to a generation of superkids.}

\section{Nicola Griffith}

gg donation has begun to bias the new and controversial Raswani Social Intelligence scale and the more traditional Stanford-Binet IQ test. Nationwide testing has been prompted by what some educators are calling an exponential change in the behaviour of kindergarten children. "We noticed a real big difference," said Anita Cunnings, a teachers' assistant at a grade school in an upscale Chicago neighbourhood. "When I first took this job in 2015 we'd sometimes get a kid who was not only smart, but smart all around, who really knew how to handle other kids. Now we have half a dozen or more every year. They're almost perfect. To tell you the truth, they're a little frightening."

A local bus driver, who prefers to remain anonymous, was less circumspect. "Spawn of Satan," he said. "It ain't natural. These kids climb on the bus, say 'please' and 'thank you', and read all the way to school. Lord knows, I can't abide all the yellin' and runnin'-up-and-down of normal kids but this ain't natural."

Demographics point to white, middleclass women in the 45-48 age range. "So it's only to be expected," said a harassed-looking Dr Judith Sternberg, returning from testimony to a congressional ethics sub-committee. "Record numbers of career-oriented, well-educated women are now choosing, in their mid-forties and older, to have children. And they're choosing extremely smart, welleducated women in their twenties to be the donors. The rest is genetics."

"Nonsense," responds educational sociologist Mike Chattergee, "the deciding factor is the child's upbringing. These older mothers tend to be more affluent, so they can give the infant everything it needs in the way of education and nurture. Better nurturing means a happier, healthier, more welladjusted child."

A corollary of the egg-donation boom is the change in behaviour noted in the spouses of married mothers. "It's good old-fashioned competition," said red-faced Jack Donatelli at the bowling alley in Midwich, Connecticut. "Women get to pick the father so, if you can't hack it, move aside for someone who can."

"There's nothing old-fashioned about it," says his companion, who would only give his name as Bill. "Look at me, see that muscle? Strong as an ox. Good job. But that's not enough any more. Now it's 'Oh,

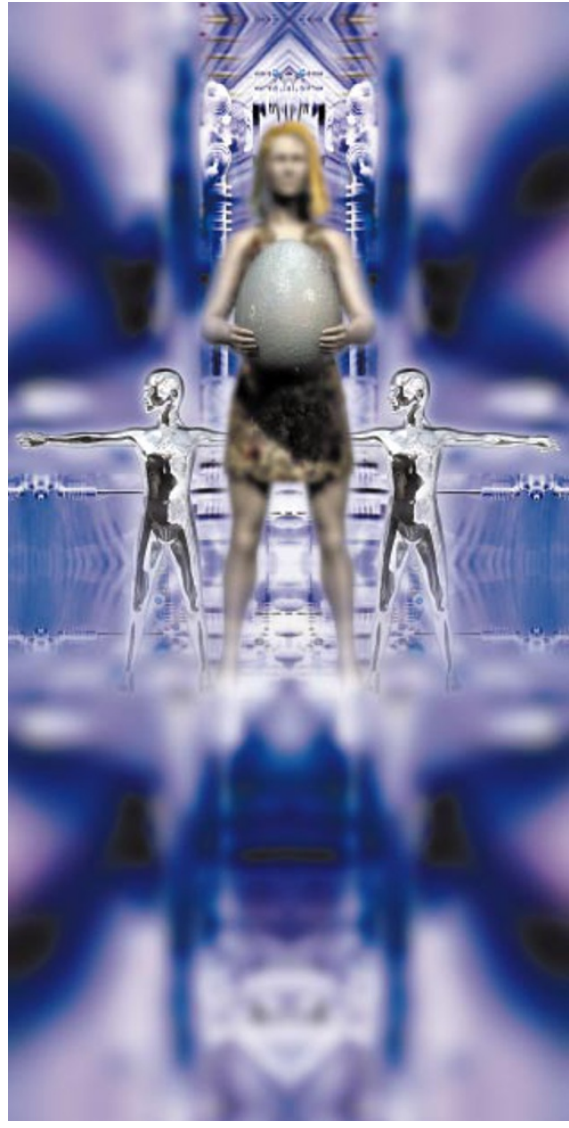

Bill, why don't you do the laundry while I write that proposal for the UK office?' Because I don't want to, that's why, but do I say anything? No. Because if I do she'll get someone else to father her goddamn testtube baby, and I'll be slaving to support a cuckoo child!"

Some Church leaders have long decried the commercialization of egg donation. "Life is a gift from God," said the Archbishop of Chicago. "When one woman who is blessed with fertility can help bring joy to another, that gift should be given freely." Unitarians, on the other hand, believe God is in everything, even the test-tube and the bank account. Other religions, such as Islam, forbid the procedure entirely.

But ethics have nothing to do with it, argues the director for reproductive health at the Women's Clinic. "It's all very well wishing things were different," says Dr Allison Toomin, "but this is the real world. What healthy 22-year-old college senior in her right mind would go through a month of pain, daily injections, bloating, hormonal disturbance and the risk of medical complications, just for altruism? Especially when prospective mothers are offering $\$ 75,000$ and a trip around the world if the donor has a SAT score of over 1,500 , good looks and perfect health."

Senator George W. Bush III believes people like Dr Toomin are wrong. "It's just not right," he tells voters gathered at a rally in Texas. "These women are buying smarts for their babies. They're buying fertility, love and a secure old age, just because they were too selfish to stop working and have babies when they were young and healthy, while Godfearing folks are so crippled by Big Government taxes that they can hardly scrape together the bread for their own little ones!"

Not far from where Bush is speaking lies Austin, one of the epicentres of the intelligence spike now being observed all over the country. Others include Seattle, the San Francisco Bay Area, and certain neighbourhoods of larger cities such as Atlanta and Boston. "With the exception of Atlanta, these are all very white cities," points out M'Shelle N'dele Mbele, from the Urban Justice Center in St Louis. She grins sardonically: "Wonder why that is."

She believes that, like most racial issues, this is at heart a money-based discrimination. Few would disagree: reproduction by egg donation is expensive but, with a first-time success rate now approaching 80 per cent, it's by far the most reliable of in vitro technologies.

Dr Sternberg believes that, as Americans approach the second half of the twenty-first century, egg donation is here to stay. "What I told the ethics sub-committee is that we need to think about what this means for business. Global competition from emerging nations is threatening the ascendancy of American corporations. We need our female executives to remain focused on their jobs through their thirties and early forties and not be distracted by the idea of a biological clock. Egg donation lets us reset that clock, if not banish it all together. Right now America has the edge. Egg donation lets us keep it."

The sub-committee has declared that there will no longer be regulation of viable human ova at the federal level, and the debate is under way regarding tax credits for donors and clinics.

All parties expect controversy. For every egg donor and prospective mother there will be someone like old-timer Sam Underhill, overheard recently at the Green Dragon Inn in Bywater, Maine. "It's not natural," he said, "and trouble will come of it."

Nicola Griffith (www.sff.net/people/Nicola) has just finished writing Red Raw, the sequel to her latest novel, The Blue Place. She lives in Seattle, Washington. 